medRxiv preprint doi: https://doi.org/10.1101/2021.02.23.21252238; this version posted February 24, 2021. The copyright holder for this preprint (which was not certified by peer review) is the author/funder, who has granted medRxiv a license to display the preprint in perpetuity.

It is made available under a CC-BY-ND 4.0 International license .

\title{
Contact patterns and HPV-genotype interactions yield heterogeneous HPV-vaccine impacts depending on sexual behaviours: an individual-based model
}

\author{
Mélanie Bonneault ${ }^{1,2,3}$, Chiara Poletto ${ }^{4}$, Maxime Flauder ${ }^{1,2}$, Didier Guillemot ${ }^{1,2}$, Elisabeth \\ Delarocque-Astagneau ${ }^{2}$, Anne CM Thiébaut ${ }^{3 \circ}$ and Lulla Opatowski ${ }^{1,2 \circ}$
}

\author{
${ }^{1}$ Epidemiology and Modelling of Antibiotic Evasion Unit, Institut Pasteur, 75475 Paris Cedex 15, \\ France \\ 2Université Paris-Saclay, UVSQ, Inserm U1018, CESP, Anti-infective Evasion and \\ Pharmacoepidemiology Team, 78180 Montigny-le-Bretonneux Cedex, France \\ ${ }^{3}$ Université Paris-Saclay, Inserm U1018, CESP, High Dimensional Biostatistics Team, 94807 Villejuif \\ Cedex, France \\ ${ }^{4}$ Inserm \& Sorbonne Université, iPLESP, 75646 Paris, France \\ ${ }^{\circ}$ These authors contributed equally to the research.
}

\section{Author for correspondence:}

Mélanie Bonneault, Institut Pasteur, Epidemiology and Modelling of Antibiotic Evasion Unit, 25, rue du Docteur-Roux, 75475 Paris Cedex 15, France.

email: melanie.bonneault@gmail.com

\begin{abstract}
Human papillomaviruses are common sexually transmitted infections, caused by a large diversity of genotypes. In the context of vaccination against a subgroup of genotypes, better understanding the role of genotype interactions and human sexual behavior on genotype ecology is essential. Herein, we present an individual-based model that integrates realistic heterosexual partnership behaviors and simulates interactions between vaccine and non-vaccine genotypes. Genotype interactions were considered, assuming a previous vaccine-genotype infection shortened (competition) or extended (synergy) the duration of a secondary non-vaccine-genotype infection. Sexual behavior determined papillomavirus acquisition and transmission: only $19.5 \%$ of active individuals with $0-1$ partner during the year, but $>80 \%$ of those with $\geq 2$ partners, were infected before vaccine introduction. Genotype interactions, despite being silent during the pre-vaccination era, markedly impacted genotype ecology after vaccination started, with a significant increase/decrease of non-vaccine prevalence for competitive/synergistic interactions. These changes were more pronounced in individuals with $\leq 3$ partners (up to $30 \%$ of prevalence modification assuming $65 \%$ vaccine coverage) but barely visible for individuals with $>3$ partners (at most $0.30 \%$ ). Results suggest that considering genotype interactions, in conjunction with heterogeneous sexual behaviors, is essential to anticipate the impact of existing and future anti-papillomavirus vaccines targeting a subgroup of genotypes.
\end{abstract}

\section{Keywords:}

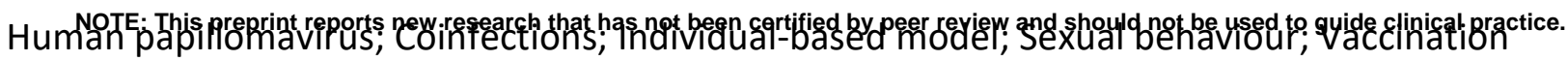


medRxiv preprint doi: https://doi.org/10.1101/2021.02.23.21252238; this version posted February 24, 2021. The copyright holder for this preprint (which was not certified by peer review) is the author/funder, who has granted medRxiv a license to display the preprint in

\section{Introduction}

Human papillomavirus (HPV) genital tract infections are among the most common sexually transmitted infections, especially in younger people (de Sanjosé et al., 2007; Markowitz et al., 2013). HPVs are characterized by a high diversity of genotypes, a few of which have been associated with cancers (cervical, vaginal, vulval, penile and anal) (Walboomers et al., 1999). Prevention has recently relied on vaccination with bivalent, quadrivalent and, more recently, nonavalent (Serrano et al., 2012) vaccines that target the subtypes carrying the highest carcinogenic risks.

Following the introduction of anti-HPV vaccines, HPV-infection prevalences with targeted genotypes have declined in several countries (Drolet et al., 2019; Tota et al., 2020). However, quantifying the vaccines' impacts on global HPV prevalence remains difficult. In particular, an increased prevalence of genotypes not included in the vaccine, known as genotype replacement, is a potential risk. Therefore, when vaccinating against a subgroup of genotypes, prediction of vaccine impact requires better understanding of whether genotypes interact and, if so, how.

In fact, simultaneous, within-host co-infection by two genotypes can affect each virus genotype's load, cell-infection ability and/or infection duration (McLaughlin-Drubin and Meyers, 2004; Murall et al., 2014; Xi et al., 2009). On the one hand, some evidence indicates that HPV genotypes may compete (Biryukov and Meyers, 2018; McLaughlin-Drubin and Meyers, 2004; Xi et al., 2009); on the other, multiple infections were commonly observed before vaccine introduction (Chaturvedi et al., 2011; Mejlhede et al., 2010; Mendez et al., 2005; Spinillo et al., 2009). The mechanisms leading to the co-existence of widely diverse HPV genotypes in populations have not yet been definitively elucidated. Some researchers argue co-existence is consistent with genotypes acting independently of each other (Chaturvedi et al., 2011; Vaccarella et al., 2013), while others suggest that the observed clustering of distinct HPV genotypes is due to between-genotype interactions (Mejlhede et al., 2010; Merikukka et al., 2011; Spinillo et al., 2009).

Previous HPV-transmission models formalizing interactions between HPV genotypes have not yet been able to reproduce simultaneously the complex aspects of HPV biology and individual behaviors. So far, models accounting for genotype interactions have been based on homogenousmixing assumptions (Elbasha and Galvani, 2005; Pons-Salort et al., 2013; Poolman et al., 2008), although partnership may vary greatly across individuals and ages. These heterogeneities, in addition to affecting infection risk and HPV prevalence (Shiboski and Padian, 1996), could also 
medRxiv preprint doi: https://doi.org/10.1101/2021.02.23.21252238; this version posted February 24, 2021. The copyright holder for this preprint (which was not certified by peer review) is the author/funder, who has granted medRxiv a license to display the preprint in It is made available under a CC-BY-ND 4.0 International license.

markedly impact genotype co-infection, co-circulation and interaction dynamics at the population level. Indeed, theoretical study results suggested that the contact network affects the population ecology of pathogen strains (Eames and Keeling, 2006; Pinotti et al., 2019). Gray et al. consistently observed HPV-genotype-replacement differences between individuals with high-risk and low-risk behaviors (Gray et al., 2019). Therefore, an accurate accounting of sexual behavior might be essential to correctly interpret HPV observations and provide more accurate projections of the epidemiological and ecological consequences of vaccination.

Optimally, only individual-based models (IBMs) enable reproduction of the heterogeneity of individual behaviors and simulation of their effects at population levels (Auchincloss and Diez Roux, 2008). A few IBMs have been developed for HPV (Johnson et al., 2018; Matthijsse et al., 2015; Olsen and Jepsen, 2010; Van de Velde et al., 2012, 2010) but none has considered HPV-genotype interactions. Herein, we report how the interplay between genotype interactions and host behaviors determine genotype prevalence, co-infection and vaccine impact using an HPVtransmission IBM based on a realistic heterosexual network of individuals and accounting for the most prevalent HPV vaccine (V) and non-vaccine (NV) genotypes.

\section{Materials and methods}

\section{Global overview}

We developed a stochastic HPV-transmission IBM accounting for contact heterogeneity according to sex, sexual activity and age. We considered the 14 most prevalent genotypes, including two $\mathrm{V}$ (HPV-16 and -18), and 12 NV genotypes (HPV-31, -33, -35, -39, -45, -51, -52, -56, -58, -59, -66 and 68) and modelled their transmissions individually and simultaneously, exploring a range of competitive and synergistic genotype interactions. The model assumed natural acquired immunity and included vaccination implementation, assuming the vaccine provided full immunity against $\mathrm{V}$ genotype-HPV infections.

\section{Population and individual characteristics}

Individuals of both sexes enter the population at 15 years and leave it at 30 years. Individuals who exit the population are directly replaced by new 15 -year-old individuals, keeping the population stable over time. The population is divided equally by sex and age per year. Each individual is explicitly modelled for each week and characterized by his/her age, sex, partnership status (three 
medRxiv preprint doi: https://doi.org/10.1101/2021.02.23.21252238; this version posted February 24, 2021. The copyright holder for this preprint (which was not certified by peer review) is the author/funder, who has granted medRxiv a license to display the preprint in perpetuity.

It is made available under a CC-BY-ND 4.0 International license .

categories: in a relationship, available for a new partnership, or neither) and infection status for each genotype (four categories: susceptible, infected, naturally immunized or vaccinated in case of a $\mathrm{V}$ genotype).

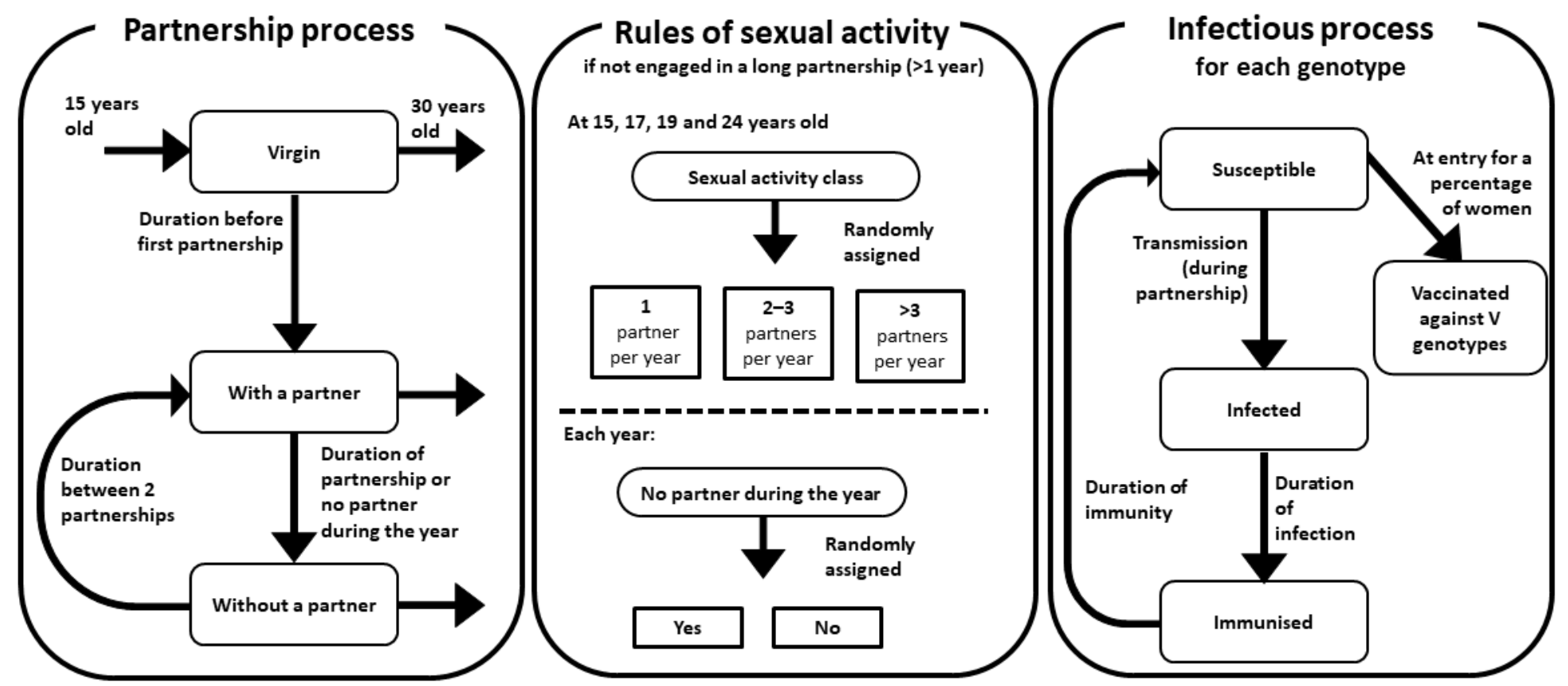

Figure 1. Schematic representation of partnership and HPV infectious processes. The partnership process is guided by the rules of sexual activity defining active and inactive periods.

\section{Modelling partnership}

We modelled heterosexual partnership behaviors as a stochastic process according to the steps summarized in figure 1 and detailed in supplementary material S1.

Model parameters describing the partnership were estimated to reproduce the reported contact patterns from the Contexte de la Sexualité en France (CSF) survey (Bajos and Bozon, 2008). The calibrated sexual behavior parameters are summarized in supplementary material S2.2.

Combinations of parameter values were simulated. After reaching prevalence equilibrium, we extracted the cumulative number of sexual partners from age 15 years to that at the time of data extraction for each individual. Because women's and men's behaviors could not be reproduced simultaneously, we first selected the combinations consistent with women's data, then chose the best combination among them with respect to men's data. 
medRxiv preprint doi: https://doi.org/10.1101/2021.02.23.21252238; this version posted February 24, 2021. The copyright holder for this preprint (which was not certified by peer review) is the author/funder, who has granted medRxiv a license to display the preprint in

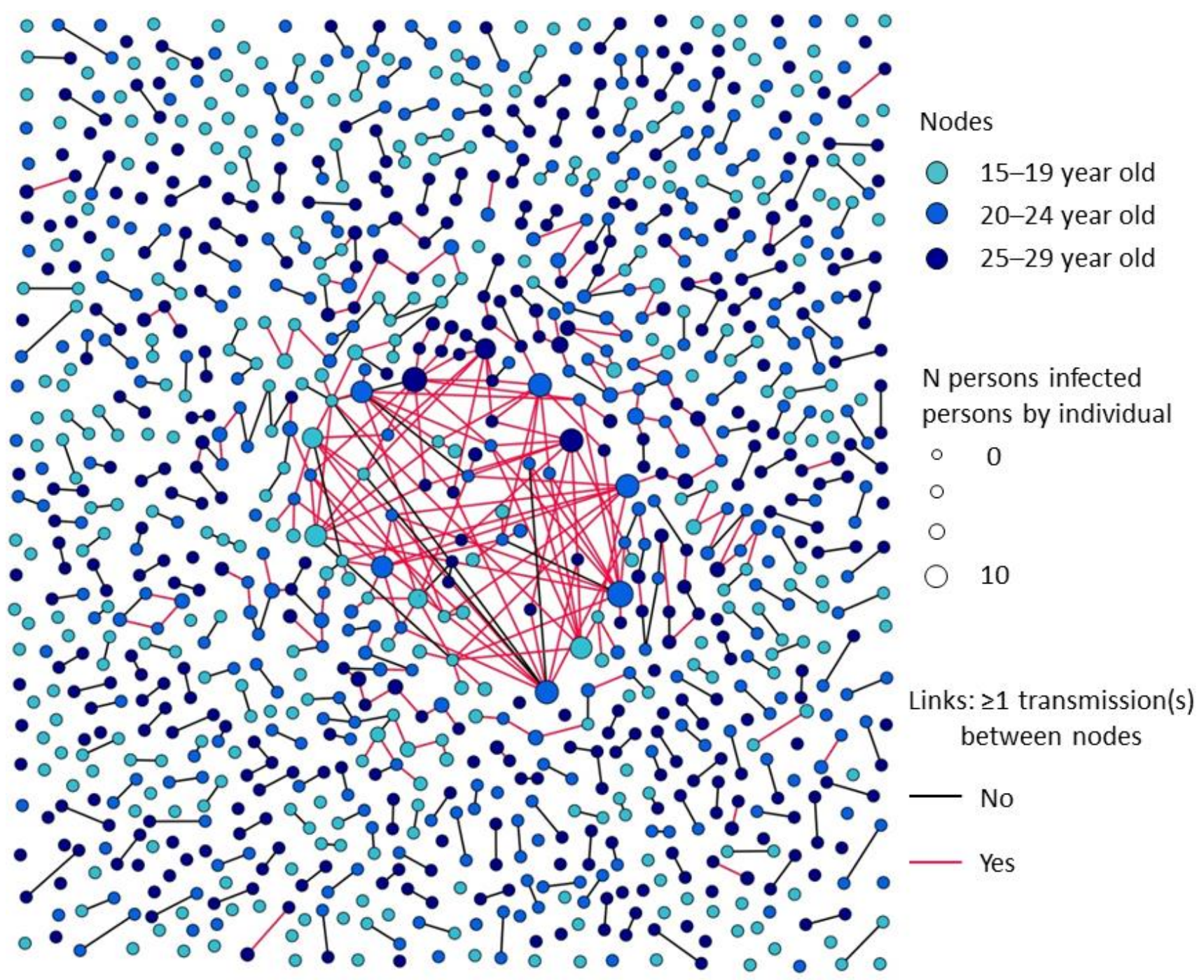

Figure 2. Partnership and HPV-transmission network throughout 1 year with a simulated population composed of 1058 individuals and 565 connections. Node colors correspond to age categories. Node diameters correspond to the number of persons infected by the individual over the 1-year study period after reaching prevalence equilibrium. If two individuals were in relationship during the year, a linking line is drawn between them, colored in red if $\geq 1$ transmission(s) occurred between them, otherwise black.

\section{Modelling HPV-genotype transmission and infection}

The transmission of any of the 14 genotypes can occur when an infected individual is in partnership with an individual not infected with that specific type (figure 1). Transmission-probability parameters are defined for $V$ and NV genotypes, respectively $\beta_{V}$ and $\beta_{N V}$, for two contacts/week. If the virus is transmitted, acquisition occurs. If an individual is infected-regardless of the genotype-his/her infection duration is sampled from an exponential distribution of mean 52 weeks, in accordance with the literature (Trottier et al., 2008). After infection clearance, the individual is assumed to have acquired natural immunity, conferring total protection against the 
medRxiv preprint doi: https://doi.org/10.1101/2021.02.23.21252238; this version posted February 24, 2021. The copyright holder for this preprint (which was not certified by peer review) is the author/funder, who has granted medRxiv a license to display the preprint in It is made available under a CC-BY-ND 4.0 International license.

same genotype for a duration defined by an exponential distribution. At the end of that period, the individual again becomes fully susceptible to that genotype. The transmission-probability parameters, $\beta_{V}$ and $\beta_{N V}$, and mean immunity duration were calibrated to reproduce prevalence before vaccine introduction (Markowitz et al., 2013), first assuming genotypes to be independent with respect to transmission and infection (neutral interaction scenario, details in supplementary material table S4, in S2.3).

With those hypotheses, the 14 viruses spread simultaneously among partners in the population. Figure 2 illustrates transmission over a simulated network.

\section{Between-genotype interaction}

We focused only on V-NV-type interactions. When an individual is co-infected with two HPV genotypes, we assumed that their co-infection history could be affected and considered the following interaction mechanism: when an individual is already infected with a $V$ genotype, the duration of a consecutive NV-genotype infection is multiplied by $\alpha$, the strength of interaction. We considered five interaction scenarios: the neutral interaction scenario $(\alpha=1)$ (see above), two scenarios with synergistic interaction in the range of values that could be satisfactorily calibrated ( $\alpha$ $=1.25$ and 1.5$)$ and two symmetrical competitive interaction scenarios ( $\alpha=0.8$ and 0.67$)$. We also explored alternative hypotheses of interaction (changing infection acquisition instead of duration, bilateral between V-and NV-genotype groups or universal between any genotypes instead of unilateral V/NV interaction) at one competition (0.8) and synergy level (1.25) as sensitivity analyses in supplementary material S6.

\section{Vaccine introduction}

We focused on the immunization schedule against high-risk genotypes that had prevailed for more than a decade in most countries (ECDC, 2020). We assumed that immunization conferred full protection (100\% efficacy) against HPV-16 and -18 genotypes for at least 15 years. We introduced vaccination with varying coverage after prevalence equilibrium was reached and ran the model for 50 additional years. We also examined the impact of targeting $<15$-year-old women with the highest infection and transmission risks as an additional sensitivity analysis (results in supplementary material S4.6). 
medRxiv preprint doi: https://doi.org/10.1101/2021.02.23.21252238; this version posted February 24, 2021. The copyright holder for this preprint (which was not certified by peer review) is the author/funder, who has granted medRxiv a license to display the preprint in It is made available under a CC-BY-ND 4.0 International license.

Table 1. Model parameters

\begin{tabular}{|c|c|c|c|}
\hline Definition & Stratification by & Default & Reference \\
\hline Population size, $n$ & & 800,000 & Fixed \\
\hline \multicolumn{4}{|l|}{ Partnership parameters } \\
\hline $\begin{array}{l}\text { Age at first partnership (weeks) } \\
\qquad A_{\text {first }} \sim \exp \left(\lambda_{\text {first }}\right)+\text { delay }_{\text {first }}\end{array}$ & Sex & $\begin{array}{l}\text { SM S1.1, } \\
\text { figure S1 }\end{array}$ & Fitted \\
\hline \multicolumn{4}{|l|}{$\lambda_{\text {first }}+$ delay $_{\text {first }}:$ mean value of age at first partnership } \\
\hline Individuals in each sexual activity group, $\%$ & $\begin{array}{l}\text { Sex; age group }(15- \\
17 ; 18-19 ; 20-24 \\
25-29)\end{array}$ & $\begin{array}{l}\text { SM tables S1 \& } \\
\text { S4 }\end{array}$ & $\begin{array}{l}\text { (Bajos and } \\
\text { Bozon, 2008) \& } \\
\text { fitted for age } \\
\text { group 15-17 }\end{array}$ \\
\hline Individuals without a partner during year; \% & Sex; age group & $\begin{array}{l}\text { SM tables S1 \& } \\
\text { S4 }\end{array}$ & $\begin{array}{l}\text { (Bajos and } \\
\text { Bozon, 2008) \& } \\
\text { fixed for age } \\
\text { group 15-17 }\end{array}$ \\
\hline $\begin{array}{l}\text { Average age of selected partners } \\
\qquad A_{\text {new_partner }}=a_{i}+\mathcal{N}\left( \pm M_{a_{p}}, \sigma_{a_{p}}^{2}\right)\end{array}$ & Sex & SM Fig. S2 & Fitted \\
\hline \multicolumn{4}{|l|}{$a_{i}:$ age of individual $i$} \\
\hline \multicolumn{4}{|l|}{$\begin{array}{l}M_{a_{p}} \text { : average value of age difference between partners } \\
\text { (if partner is a woman } M_{a_{p}}>0 \text { otherwise } M_{a_{p}}<0 \text { ) }\end{array}$} \\
\hline \multicolumn{4}{|l|}{$\sigma_{a_{p}}^{2}:$ variance value of age difference between partners } \\
\hline Duration of partnership (weeks) & Sexual activity group & SM table S4 & Fitted \\
\hline Duration of single state (weeks) & Sexual activity group & SM table S4 & Fitted \\
\hline $\begin{array}{l}\text { Partner-search duration before mixing between groups of } \\
\text { sexual activity (weeks) }\end{array}$ & Sexual activity group & SM table S4 & Fitted \\
\hline Sexual contact rate per week & & 2 & Fixed \\
\hline \multicolumn{4}{|l|}{ Infection parameters } \\
\hline Transmission-probability parameter $\left(\beta_{N v} / \beta_{V}\right)$ & NV/V & $\begin{array}{l}0.125 \& 0.16 \\
(\mathrm{SM} \text { table S4) }\end{array}$ & Fitted \\
\hline $\begin{array}{l}\text { Duration of infection } D_{I N F} \\
\qquad D_{I N F} \sim \exp \left(\lambda_{D_{-} \text {inf }}\right)\end{array}$ & & 52 weeks & $\begin{array}{l}\text { (Trottier et al., } \\
\text { 2008) }\end{array}$ \\
\hline \multicolumn{4}{|l|}{$\lambda_{D_{-} \text {inf }}:$ mean duration of infection } \\
\hline $\begin{array}{l}\text { Duration of immune state } D_{I M} \\
\qquad D_{I M} \sim \exp \left(\lambda_{D_{-} i m}\right)\end{array}$ & & $\begin{array}{l}12 \text { (SM Table } \\
\text { S4) }\end{array}$ & Fitted \\
\hline \multicolumn{4}{|l|}{$\lambda_{D_{-} i m}:$ mean duration of immune state } \\
\hline Genotype-interaction parameter, $\alpha$ & & $\begin{array}{l}\text { Neutral: } 1 \\
\text { Synergy: } 1.25 ; \\
1.5 \\
\text { Competition: } \\
0.67 ; 0.8\end{array}$ & Fixed \\
\hline Vaccination-coverage rate & & $\begin{array}{c}65 \% \text { (in SM } \\
25 \%) \\
\end{array}$ & Fixed \\
\hline Time of vaccine introduction & & 20 years ago & Fixed \\
\hline
\end{tabular}

SM, supplementary material.

\section{Parameter calibration}

We used the least-squares distance minimization to measure the adequacy between simulated 
medRxiv preprint doi: https://doi.org/10.1101/2021.02.23.21252238; this version posted February 24, 2021. The copyright holder for this preprint (which was not certified by peer review) is the author/funder, who has granted medRxiv a license to display the preprint in It is made available under a CC-BY-ND 4.0 International license.

results and real data. All parameters, calibrated or taken from the literature, are defined in table 1. Ranges of tested values and estimated values are detailed in supplementary material S2 and table S4 for each calibrated parameter.

\section{Analysis of results}

To characterize V-and NV-genotype distributions, we considered infection, co-infection, acquisition and transmission according to sexual activity groups (detailed in supplementary material S3.2).

First, we compared HPV-infection spread through the contact network for varying genotypeinteraction strengths with that under the neutral interaction scenario before vaccine introduction. Second, we examined how hypothetical genotype-interaction scenarios would affect HPV-genotype ecology after vaccine introduction in comparison with the neutral interaction scenario (detailed methods in supplementary material S3.3).

\section{Results}
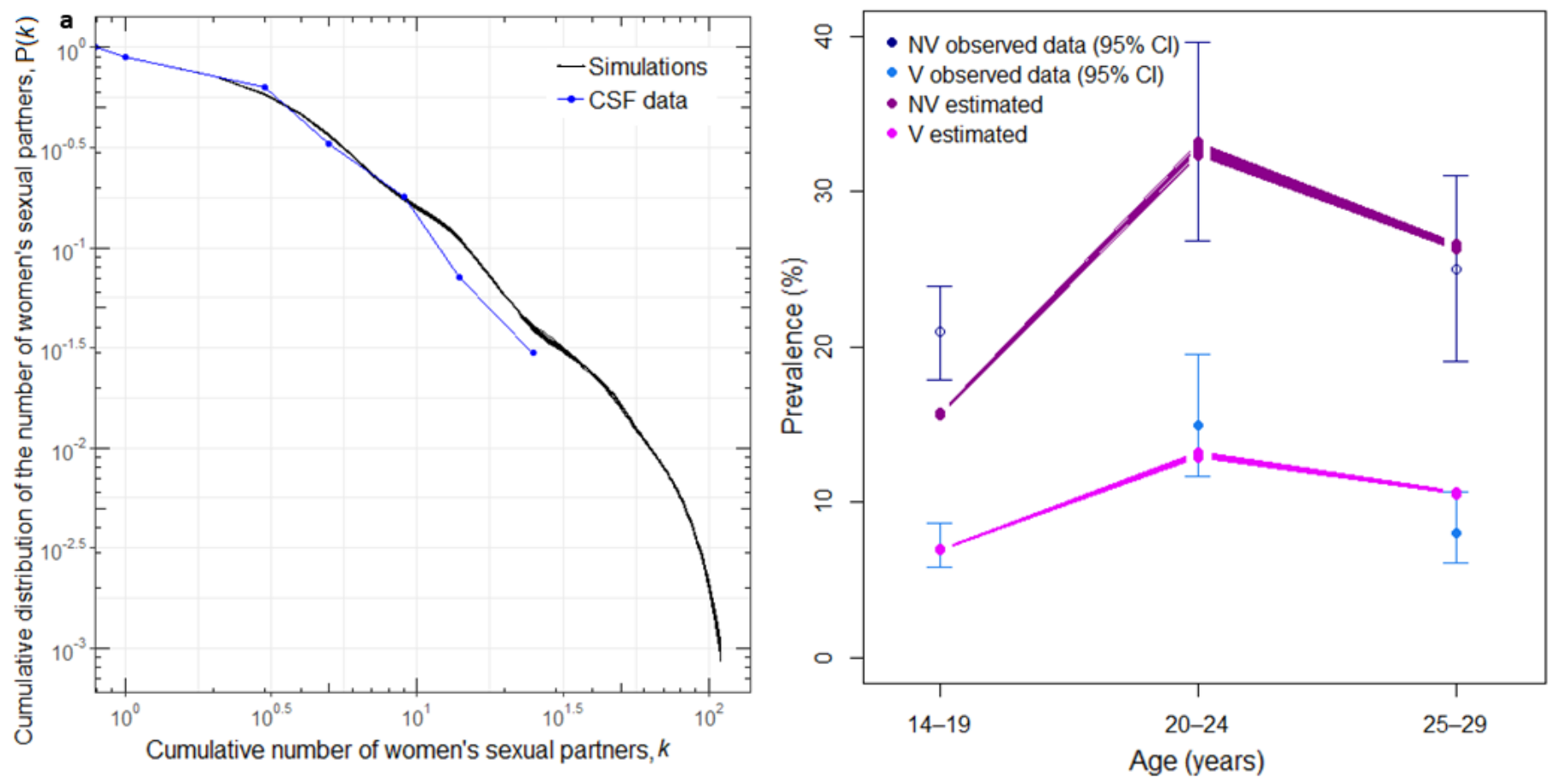

Figure 3. Calibration of partnerships and HPV-transmission parameters. (a) Cumulative distribution of the number of sexual partners for women 18-30 years old. (b) NV- and V-genotype prevalences with $95 \%$ confidence interval (Cl) reported in (Markowitz et al., 2013) (circles) and results of 10 simulations, each obtained as the average value over 10 years after reaching prevalence equilibrium (connecting lines). 
medRxiv preprint doi: https://doi.org/10.1101/2021.02.23.21252238; this version posted February 24, 2021. The copyright holder for this preprint (which was not certified by peer review) is the author/funder, who has granted medRxiv a license to display the preprint in perpetuity.

It is made available under a CC-BY-ND 4.0 International license .

\section{Model simulations reproduced observed partner and HPV-prevalence distributions by age}

Compared to CSF results, distributions of total numbers of partners were reproduced with limited variability (figure 3a), minor overestimation of the percentage of women with $>10$ partners and underestimation of the percentage of men with $>3$ partners (figure S3).

Under the neutral interaction scenario, the model accurately reproduced realistic distributions of V-and NV-genotype prevalences by age category, with the characteristic bell-shaped curves and prevalence peaks between 20 and 24 years (figure $3 b$ ). The transmission-probability parameter calibrated for $V$ genotypes was higher than that of NV genotypes $\left(\beta_{V}=0.16\right.$ and $\beta_{N V}=0.125$, respectively, with 12 weeks of calibrated immunity duration). In simulations, the average percentage of ever-infected individuals increased sharply with age, reaching $71.4 \%$ at 29 years.
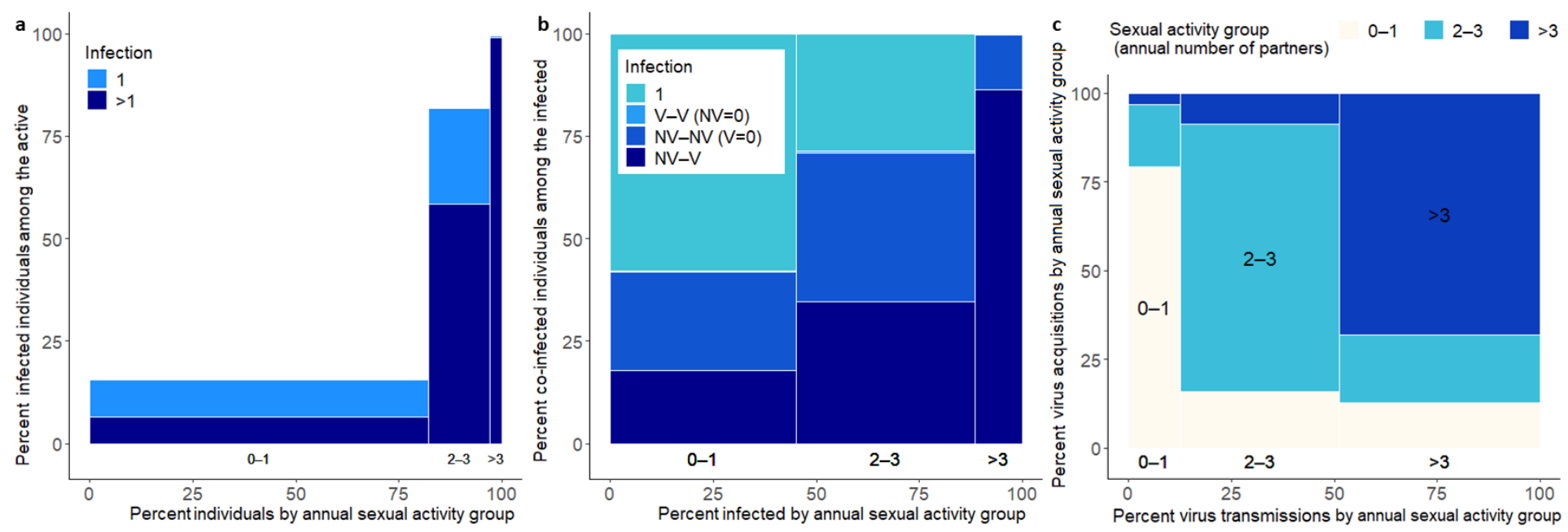

Figure 4. NV- and V-genotype infections, co-infections and transmissions according to the annual number of partners. (a) Mean percentages of individuals with single and multiple infections among the active population over 20 simulations according to their number of partners during the past year at prevalence equilibrium $t=640$ weeks. (b) Mean percentages of individuals infected with a single NV or V genotype, with the two $\mathrm{V}$ types but no NV type, with $>1$ distinct NV types but no $\mathrm{V}$ type, and with $V$ and NV types among the infected population over 20 simulations according to their annual number of partners at prevalence equilibrium time. (c) Percentages of virus transmissions according to sexual activity group of the transmitter during the year. For each transmission group ( $\mathrm{x}$-axis), the sexual activity group distribution of the acquirers is represented on the y-axis.

\section{Infections and co-infections did not spread homogeneously throughout the network under the neutral interaction scenario}

Individuals infected with a single or multiple genotype(s) were distributed among the population as a function of the number of partners during the past year (figure 4a). After reaching prevalence equilibrium, $33.3 \%$ of the active population were infected $(27.7 \%$ of the whole population) and 
medRxiv preprint doi: https://doi.org/10.1101/2021.02.23.21252238; this version posted February 24, 2021. The copyright holder for this preprint (which was not certified by peer review) is the author/funder, who has granted medRxiv a license to display the preprint in It is made available under a CC-BY-ND 4.0 International license .

$20.3 \%$ were co-infected ( $61.5 \%$ of the infected). Among the infected population (figure $4 \mathrm{~b}), 45.2 \%$ of infected individuals had 0-1 partner during the past year (15.5\% prevalence for this group), $43.2 \%$ had $2-3$ partners (81.7\%) and $11.6 \%$ had $>3$ partners $(99.5 \%)$. The co-infection percentage increased with annual sexual activity, with only $8.2 \%$ of active individuals with $0-1$ partner being co-infected, as opposed to $>60 \%$ of individuals with $\geq 2$ partners. Co-infections with multiple $V$ genotypes but no NV genotype were extremely rare ( $0.35 \%$ of infected individuals). Indeed, $33.1 \%$ of the infected population were V-NV-genotype co-infected.

As shown in figure 4c, HPVs were mostly transmitted by individuals with $\geq 2$ partners $(41.2 \%$ by individuals with $2-3$ partners and $47.5 \%$ by individuals with $>3$ partners in the year); $95.5 \%$ of individuals with $>3$ partners and $48.3 \%$ of individuals with $2-3$ partners transmitted at least once during the year. Moreover, transmission mostly occurred within the sexual activity group (comparison with partnership matrix in supplementary material S4.2).

\section{Alternative genotype-interaction scenarios did not modify pre-vaccine infection and co-infection patterns}

Before vaccination was introduced, all simulations were fitted to HPV-genotype prevalences within the range of assessed competitive, neutral and synergistic interactions (figure S5).The strength of interaction did not markedly affect co-infection patterns either (figure S8a, b and c). We further verified that this lack of influence did not simply reflect differences in transmission probability $\beta_{N V}$, resulting from calibrating the model for varying interaction strengths (supplementary material S5.2).

\section{V and NV prevalences were impacted differently according to sexual activity group post-vaccine introduction}

After introducing vaccination, hypotheses regarding genotype-interaction impacted NV-prevalence trends (figures 5 and S6 for a uniform 65\% vaccine coverage among women; results for $25 \%$ coverage are given in supplementary material S4.5). In all genotype-interaction scenarios, Vprevalence range decreased (difference relative to pre-vaccine era) by $83.7 \%$ to $85.9 \%$ for individuals with $0-1$ and $2-3$ partners, and only $51.3 \%$ to $53.2 \%$ for individuals with $>3$ partners (figures S6 and 5a). Conversely, NV-genotype prevalences changed markedly after vaccine introduction for all interaction strengths compared to the neutral scenario. Competitive or synergistic interaction scenarios, respectively, led to higher or lower NV prevalence compared to 
medRxiv preprint doi: https://doi.org/10.1101/2021.02.23.21252238; this version posted February 24, 2021. The copyright holder for this preprint (which was not certified by peer review) is the author/funder, who has granted medRxiv a license to display the preprint in perpetuity.

It is made available under a CC-BY-ND 4.0 International license .

the neutral scenario (figures S6, and S9a and d). As expected, the stronger the interaction strength (the more it deviates from 1), the greater the NV-prevalence percentage difference (for additional information, see the supplementary material on sensitivity analysis S5.4). The NV-prevalence effect was stronger in individuals with 0-1 partner (median $25.9 \%$ for $\alpha=0.67$ and $-32.0 \%$ for $\alpha=1.5$ ) than in individuals with 2-3 partners (median 14.2\% for $\alpha=0.67$ and $-23.5 \%$ for $\alpha=1.5$ ) (figure $5 b$ ). For individuals with $>3$ partners during the year, prevalence did not change appreciably (median $0.08 \%$ for $\alpha=0.67$ and $-0.25 \%$ for $\alpha=1.5)$.
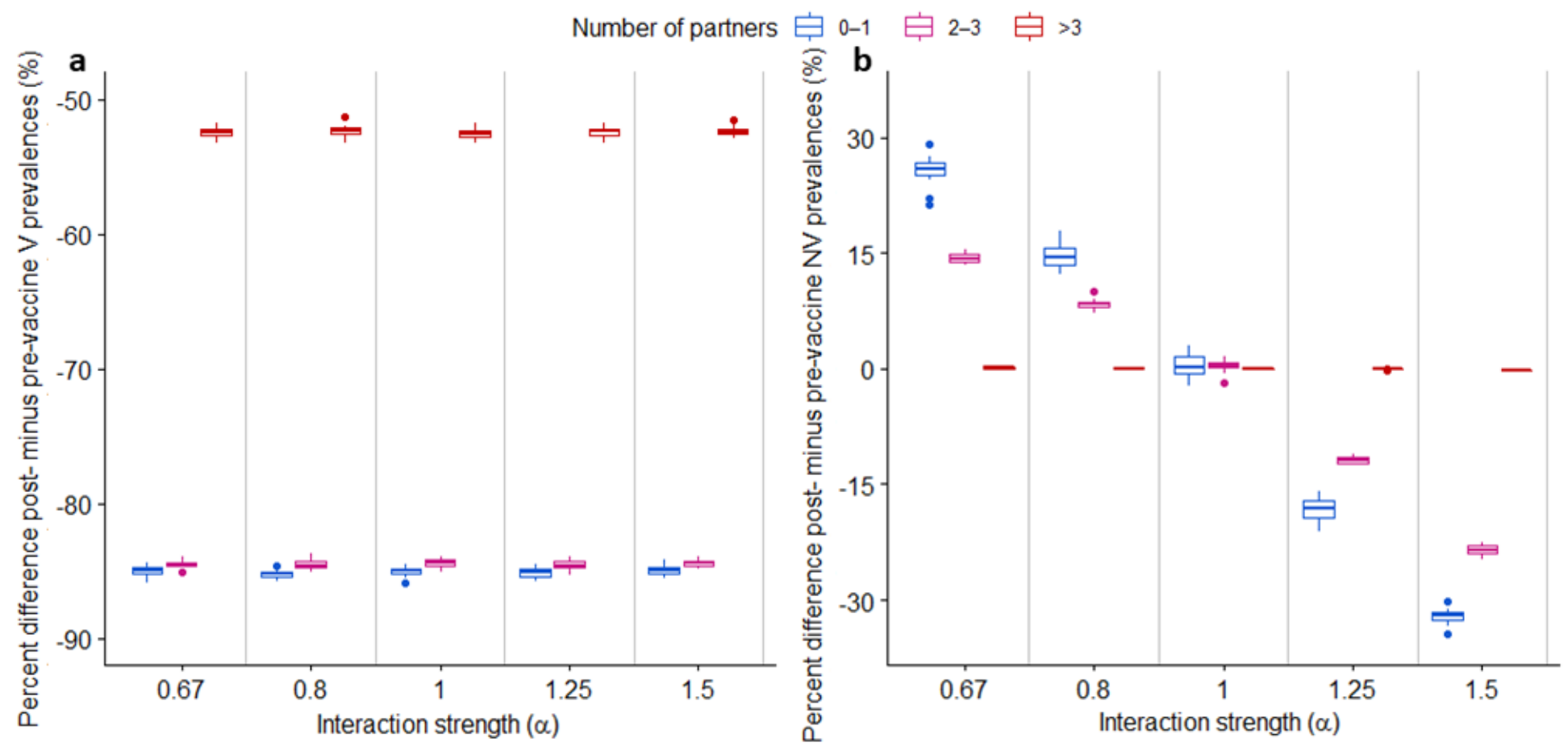

Figure 5. Percentage differences between post- and pre-vaccine prevalences of (a) V and (b) NV genotypes under $65 \%$ vaccine coverage by sexual activity group and interaction scenarios. Vaccine was introduced after reaching prevalence equilibrium. Average prevalences were assessed at three distinct times each before and after vaccine introduction. Boxplots show the variability over 20 simulations for each interaction scenario (bold horizontal line inside the box is the median, lower and upper box limits are the 1st and 3rd quartiles, antennae correspond to 1.5 times the interquartile range and circles mark the values outside this range).

Sensitivity analyses showed that targeting high-risk sexual activity groups instead of vaccinating all women $<15$ years old led to greater reduction of V-type prevalence for individuals with $>3$ partners but did not 
medRxiv preprint doi: https://doi.org/10.1101/2021.02.23.21252238; this version posted February 24, 2021. The copyright holder for this preprint (which was not certified by peer review) is the author/funder, who has granted medRxiv a license to display the preprint in It is made available under a CC-BY-ND 4.0 International license.

modify NV-prevalence-variation patterns across sexual activity groups (supplementary material S4.6).

Furthermore, among the other hypotheses tested for genotype interactions (supplementary material S6), it appeared that only interactions by HPV-genotype groups could be detected within the considered range of interaction strengths. Moreover, when notable NV-prevalence differences were observed, compared to the neutral interaction scenario, they appeared only among the less active individuals.

\section{Discussion \& conclusion}

We found that heterogeneous contact behaviors and natural immunity acquired after infection were essential to reproduce the bell-shaped curve of HPV-infection prevalence by age category. Calibrated interaction scenarios revealed no notable differences in terms of infection and coinfection patterns before vaccine introduction. However, thereafter, interactions mattered: competitive interactions led to significantly increased NV prevalence, while the opposite was seen for synergistic interactions. Of interest, our results suggested that the interaction effect on prevalence was stronger for less active individuals.

While it is expected that the introduction of the nonavalent vaccine will again modify the prevalence equilibrium, solid comprehension of the potential impacts of the initial bi- and quadrivalent vaccines is required to improve understanding of changing HPV ecology. Our IBM allowed us specifically to examine the impact of vaccination scenarios of $\mathrm{V}-$, NV- or V-NV genotype interactions. Two former studies based on compartmental models analyzed the impact of genotype interactions on acquisition or clearance, without explicitly modelling heterogeneous sexual behaviors as IBMs do (Elbasha and Galvani, 2005; Pons-Salort et al., 2013). The results of both showed that, when considering between-genotype interactions, NV-genotype prevalences could be modified by vaccine introduction.

Based on our simulations for the prevaccine era, $71.4 \%$ of individuals were infected with at least one HPV genotype by 29 years of age. This simulation finding agrees with previous reports of $80 \%$ infected at least once during their lifetime (Santé publique France, 2019), acknowledging that a limited number of new infections can be acquired after 30 years of age and that only 14 high-risk HPV among 37 detectable sexually transmitted genotypes were modelled here. Furthermore, coinfections were frequent in our results, representing about two-thirds of HPV-positive women for all interaction strengths tested. That outcome, although at the upper limit of the interval, is 
medRxiv preprint doi: https://doi.org/10.1101/2021.02.23.21252238; this version posted February 24, 2021. The copyright holder for this preprint (which was not certified by peer review) is the author/funder, who has granted medRxiv a license to display the preprint in It is made available under a CC-BY-ND 4.0 International license.

consistent with $20 \%-70 \%$ co-infections among all infections described in observational studies (Chaturvedi et al., 2011; Mejlhede et al., 2010; Mendez et al., 2005; Spinillo et al., 2009). Pertinently, herein, all co-infections were assumed to be detected and counted, unlike epidemiological studies in which, depending on the techniques used, detection of multiple infections may be more-or-less sensitive (Qu et al., 1997).

Concerning transmission probabilities under the neutral interaction scenario, our estimated $\beta_{N^{-}}$ and $\beta$-transmission probabilities were $0.125 /$ and $0.16 /$ week, respectively. Considering two sexual acts per week on average, our results are of the same order of magnitude as values from other IBMs, range 0.048-0.95 per sex act (Johnson et al., 2018; Matthijsse et al., 2015; Olsen and Jepsen, 2010; Van de Velde et al., 2012, 2010). Nevertheless, our estimates strongly depend on infection duration and the definition of immunity. Notably, assuming a probability $<1$ to acquire typespecific, natural, lifelong immunity yielded higher transmission probabilities, range 0.5-0.95 (Johnson et al., 2018; Van de Velde et al., 2012, 2010). In addition, either with acquired immunity during a limited period, as assumed herein, or without immunity, modelling showed lower transmission probabilities, range 0.048-0.3 (Matthijsse et al., 2015; Olsen and Jepsen, 2010).

Pertinently, the pre-vaccine situation could be explained by totally distinct interaction hypotheses. Moreover, vaccine introduction more strongly impacted NV prevalence in less active individuals, whereas any prevalence modification would be expected to be seen in high-risk groups (Gray et al., 2019; Tota et al., 2013). Considering transmission throughout the network, the acquisition risk for any individual depends on two factors: the virus-circulation level in the population (defined as the transmission rate, and durations of infection and immunity), and the number of partners. As those numbers remain unchanged on average, the vaccination impact depends on virus-transmission potential before vaccination. That potential was substantially higher for the >3-partner group than the low- or intermediate-activity groups.

Our results obtained with this methodology should also be interpreted in light of the following limitations. First, aggregated data were used, impeding a precise description of individual trajectories throughout their sexual lifetimes, such as switching between sexual activity groups, and durations of partnership and between two partnerships. As previously stressed in other studies, our model was unable to perfectly reproduce the distributions of the numbers of partners for both sexes. Indeed, CSF data included more men with high numbers of partners than women (Bajos and Bozon, 2008). Differential sex-dependent reporting bias was observed previously (Fenton et al., 2001; Mitchell et al., 2019) and may, in part, be at the origin of the discrepancy between model and 
medRxiv preprint doi: https://doi.org/10.1101/2021.02.23.21252238; this version posted February 24, 2021. The copyright holder for this preprint (which was not certified by peer review) is the author/funder, who has granted medRxiv a license to display the preprint in It is made available under a CC-BY-ND 4.0 International license.

data. To overcome that difficulty, we focused on women's data to fit our model and estimate parameters, while trying to conform to men's data in terms of cumulative partner numbers. The resulting distribution of total numbers of partners was typical of a partnership network with a power law distribution (Liljeros et al., 2001; Schneeberger et al., 2004).

Second, because no data are available on HPV-infection prevalence by age and $V$ genotype for the pre-vaccine era in France, we used distributions reported for the US, whose current HPV epidemiology is similar (Bruni et al., 2010; de Sanjosé et al., 2007). NV-prevalence simulations appeared to be underestimated for 15-19-year-olds, compared with US data (Markowitz et al., 2013). Unfortunately, partnership and infection data are scarce for this age category, making calibration difficult. We think that underestimation for 15-19-year-olds had little impact on our results for all ages combined. The average prevalence of $27.7 \%$ for the whole $15-30$-year-old population obtained in our simulations before vaccination is comparable to those reported in epidemiological studies in France, range $25.1 \%-28.5 \%$ for 15-79-year-old women with normal vaginal smear cytology (Dalstein et al., 2003; Monsonego et al., 2005; Riethmuller et al., 1999).

Third, to keep our model relatively simple, only two transmission-probability parameters were estimated for all genotypes, despite studies having reported that HPV-16 and -18 prevalences may differ from one another and from those of other HR genotypes (Markowitz et al., 2013). Hence, our estimated transmission-probability parameter $\beta_{V}$ can be considered an average probability for HPV16 and -18 , and that of $\beta_{N V}$ an average probability for the 12 high-risk NV types. Similarly, because epidemiological study results have not yet demonstrated clear between-genotype differences for infection duration (Ramanakumar et al., 2016; Trottier et al., 2008), a unique parameter was defined for all genotypes.

Fourth, while much is still unknown about immunity following HPV infection (Gravitt and Winer, 2017), we chose to define immunity as total protection against reinfection to the same genotype during a fixed duration, identical for all genotypes, in accordance with findings suggesting some degree of protection against reinfection (Ho et al., 2002; Safaeian et al., 2010). Previous HPV modelling considered either complete lifelong immunity, partial or waning immunity, acquired immunity during a defined period, or protection increasing with the number of past infections (Franceschi and Baussano, 2014). Matthijsse et al. showed that assuming natural immunity in their model was necessary to reproduce the age-specific HPV-infection patterns and that assuming full genotype-specific immunity yielded the best calibration results (Matthijsse et al., 2015). We made 
medRxiv preprint doi: https://doi.org/10.1101/2021.02.23.21252238; this version posted February 24, 2021. The copyright holder for this preprint (which was not certified by peer review) is the author/funder, who has granted medRxiv a license to display the preprint in It is made available under a CC-BY-ND 4.0 International license.

the same observation herein, after testing various immunity hypotheses (data not shown).

Finally, while interaction mechanisms between HPV genotypes also remain unknown, we assumed that genotype interaction would affect the infection duration of a second acquired virus. Some authors suggested that simultaneous within-host co-infection with two genotypes could impact each virus-genotype load and thus the successful infection of cells by each (Biryukov and Meyers, 2018; McLaughlin-Drubin and Meyers, 2004; Xi et al., 2009). We explored alternative interaction hypotheses in sensitivity analyses and obtained similar results for NV genotypes, when genotype interaction impacted acquisition risk instead of infection duration.

To conclude, our results confirmed that HPV infections reached not only the most sexually active but also less active individuals and unexpectedly revealed that the impact of vaccine introduction on genotype ecology could be more detectable in less active individuals. These analyses suggest that focusing on more sexually active individuals to address questions related to vaccination impact might potentially lower the ability to detect HPV-ecology variations, and highlight that public health information and prevention efforts should target all sexually active individuals, not only the population at-risk for sexually transmitted infections. Moreover, our results showed that genotypeinteraction-associated hypotheses were all consistent with the reported pre-vaccine prevalences. In the post-vaccine era, better understanding those interactions and sexual contacts is key to anticipating the long-term impact of anti-HPV vaccines with respect to the prevention of cervical and other cancers. 
medRxiv preprint doi: https://doi.org/10.1101/2021.02.23.21252238; this version posted February 24, 2021. The copyright holder for this preprint (which was not certified by peer review) is the author/funder, who has granted medRxiv a license to display the preprint in It is made available under a CC-BY-ND 4.0 International license .

\section{Funding sources}

MB was funded by the INCa [grant DOC 2017-123] and MGEN, and her work was supported by internal resources of Institut Pasteur, the French National Institute of Health and Medical Research (Inserm) and the University of Versailles Saint-Quentin-en-Yvelines (UVSQ).

\section{Authors' contributions}

$M B, C P, M F, E D A, D G, A C M T$ and LO conceptualized the project. AT and LO supervised the project. $M B, A C M T$ and $L O$ designed the model. MB and MF developed the model. MB, CP, ACMT and LO performed the network and statistical analyses and validated them. All authors approved the latest version of this article

\section{Declaration of Competing Interest}

The authors declare no conflicts of interest.

\section{Acknowledgements}

We thank Margarita Pons-Salort for helpful discussions and ideas provided early during the project. We are also grateful to Janet Jacobson for editorial assistance.

\section{Appendix A. Supplementary data}

Supplementary data associated with this article can be found, in the online version. 
medRxiv preprint doi: https://doi.org/10.1101/2021.02.23.21252238; this version posted February 24, 2021. The copyright holder for this preprint (which was not certified by peer review) is the author/funder, who has granted medRxiv a license to display the preprint in It is made available under a CC-BY-ND 4.0 International license.

\section{References}

Auchincloss, A.H., Diez Roux, A.V., 2008. A new tool for epidemiology: the usefulness of dynamicagent models in understanding place effects on health. Am. J. Epidemiol. 168, 1-8. https://doi.org/10.1093/aje/kwn118

Bajos, N., Bozon, M., 2008. Sexualité, genre et santé : les apports de l'enquête " Contexte de la sexualité en France ", Enquête sur la sexualité en France. La Découverte.

Biryukov, J., Meyers, C., 2018. Superinfection Exclusion between Two High-Risk Human Papillomavirus Types during a Coinfection. J. Virol. 92. https://doi.org/10.1128/JVI.01993-17

Bruni, L., Diaz, M., Castellsagué, X., Ferrer, E., Bosch, F.X., de Sanjosé, S., 2010. Cervical human papillomavirus prevalence in 5 continents: meta-analysis of 1 million women with normal cytological findings. J. Infect. Dis. 202, 1789-1799. https://doi.org/10.1086/657321

Chaturvedi, A.K., Katki, H.A., Hildesheim, A., Rodríguez, A.C., Quint, W., Schiffman, M., Van Doorn, L.-J., Porras, C., Wacholder, S., Gonzalez, P., Sherman, M.E., Herrero, R., CVT Group, 2011. Human papillomavirus infection with multiple types: pattern of coinfection and risk of cervical disease. J. Infect. Dis. 203, 910-920. https://doi.org/10.1093/infdis/jiq139

Dalstein, V., Riethmuller, D., Prétet, J.-L., Le Bail Carval, K., Sautière, J.-L., Carbillet, J.-P., Kantelip, B., Schaal, J.-P., Mougin, C., 2003. Persistence and load of high-risk HPV are predictors for development of high-grade cervical lesions: a longitudinal French cohort study. Int. J. Cancer 106, 396-403. https://doi.org/10.1002/ijc.11222

de Sanjosé, S., Diaz, M., Castellsagué, X., Clifford, G., Bruni, L., Muñoz, N., Bosch, F.X., 2007. Worldwide prevalence and genotype distribution of cervical human papillomavirus DNA in women with normal cytology: a meta-analysis. Lancet Infect. Dis. 7, 453-459. https://doi.org/10.1016/S1473-3099(07)70158-5

Drolet, M., Bénard, É., Pérez, N., Brisson, M., HPV Vaccination Impact Study Group, 2019. Population-level impact and herd effects following the introduction of human papillomavirus vaccination programmes: updated systematic review and meta-analysis. Lancet Lond. Engl. 394, 497-509. https://doi.org/10.1016/S0140-6736(19)30298-3

Eames, K.T.D., Keeling, M.J., 2006. Coexistence and specialization of pathogen strains on contact networks. Am. Nat. 168, 230-241. https://doi.org/10.1086/505760

ECDC, 2020. Guidance on HPV vaccination in EU countries: focus on boys, people living with HIV and 9-valent HPV vaccine introduction [WWW Document]. Eur. Cent. Dis. Prev. Control. URL https://www.ecdc.europa.eu/en/publications-data/guidance-hpv-vaccination-eu-focusboys-people-living-hiv-9vHPV-vaccine (accessed 7.2.20).

Elbasha, E.H., Galvani, A.P., 2005. Vaccination against multiple HPV types. Math. Biosci. 197, 88117. https://doi.org/10.1016/j.mbs.2005.05.004

Fenton, K.A., Johnson, A.M., McManus, S., Erens, B., 2001. Measuring sexual behaviour: methodological challenges in survey research. Sex. Transm. Infect. 77, 84-92. https://doi.org/10.1136/sti.77.2.84

Franceschi, S., Baussano, I., 2014. Naturally Acquired Immunity Against Human Papillomavirus (HPV): Why It Matters in the HPV Vaccine Era. J. Infect. Dis. 210, 507-509. https://doi.org/10.1093/infdis/jiu143

Gravitt, P.E., Winer, R.L., 2017. Natural History of HPV Infection across the Lifespan: Role of Viral Latency. Viruses 9. https://doi.org/10.3390/v9100267

Gray, P., Luostarinen, T., Vänskä, S., Eriksson, T., Lagheden, C., Man, I., Palmroth, J., Pimenoff, V.N., Söderlund-Strand, A., Dillner, J., Lehtinen, M., 2019. Occurrence of human papillomavirus (HPV) type replacement by sexual risk-taking behaviour group: Post-hoc analysis of a 
medRxiv preprint doi: https://doi.org/10.1101/2021.02.23.21252238; this version posted February 24, 2021. The copyright holder for this preprint (which was not certified by peer review) is the author/funder, who has granted medRxiv a license to display the preprint in It is made available under a CC-BY-ND 4.0 International license.

community randomized clinical trial up to 9 years after vaccination (IV). Int. J. Cancer 145, 785-796. https://doi.org/10.1002/ijc.32189

Ho, G.Y.F., Studentsov, Y., Hall, C.B., Bierman, R., Beardsley, L., Lempa, M., Burk, R.D., 2002. Risk factors for subsequent cervicovaginal human papillomavirus (HPV) infection and the protective role of antibodies to HPV-16 virus-like particles. J. Infect. Dis. 186, 737-742. https://doi.org/10.1086/342972

Johnson, H.C., Lafferty, E.I., Eggo, R.M., Louie, K., Soldan, K., Waller, J., Edmunds, W.J., 2018. Effect of HPV vaccination and cervical cancer screening in England by ethnicity: a modelling study. Lancet Public Health 3, e44-e51. https://doi.org/10.1016/S2468-2667(17)30238-4

Liljeros, F., Edling, C.R., Amaral, L.A., Stanley, H.E., Aberg, Y., 2001. The web of human sexual contacts. Nature 411, 907-908. https://doi.org/10.1038/35082140

Markowitz, L.E., Hariri, S., Lin, C., Dunne, E.F., Steinau, M., McQuillan, G., Unger, E.R., 2013. Reduction in human papillomavirus (HPV) prevalence among young women following HPV vaccine introduction in the United States, National Health and Nutrition Examination Surveys, 2003-2010. J. Infect. Dis. 208, 385-393. https://doi.org/10.1093/infdis/jit192

Matthijsse, S.M., van Rosmalen, J., Hontelez, J.A.C., Bakker, R., de Kok, I.M.C.M., van Ballegooijen, M., de Vlas, S.J., 2015. The role of acquired immunity in the spread of human papillomavirus (HPV): explorations with a microsimulation model. PloS One 10, e0116618. https://doi.org/10.1371/journal.pone.0116618

McLaughlin-Drubin, M.E., Meyers, C., 2004. Evidence for the coexistence of two genital HPV types within the same host cell in vitro. Virology 321, 173-180. https://doi.org/10.1016/j.virol.2003.12.019

Mejlhede, N., Pedersen, B.V., Frisch, M., Fomsgaard, A., 2010. Multiple human papilloma virus types in cervical infections: competition or synergy? APMIS Acta Pathol. Microbiol. Immunol. Scand. 118, 346-352. https://doi.org/10.1111/j.1600-0463.2010.02602.x

Mendez, F., Munoz, N., Posso, H., Molano, M., Moreno, V., van den Brule, A.J.C., Ronderos, M., Meijer, C., Munoz, A., Instituto Nacional de Cancerologia Human Papillomavirus Study Group, 2005. Cervical coinfection with human papillomavirus (HPV) types and possible implications for the prevention of cervical cancer by HPV vaccines. J. Infect. Dis. 192, 11581165. https://doi.org/10.1086/444391

Merikukka, M., Kaasila, M., Namujju, P.B., Palmroth, J., Kirnbauer, R., Paavonen, J., Surcel, H.-M., Lehtinen, M., 2011. Differences in incidence and co-occurrence of vaccine and nonvaccine human papillomavirus types in Finnish population before human papillomavirus mass vaccination suggest competitive advantage for HPV33. Int. J. Cancer 128, 1114-1119. https://doi.org/10.1002/ijc.25675

Mitchell, K.R., Mercer, C.H., Prah, P., Clifton, S., Tanton, C., Wellings, K., Copas, A., 2019. Why Do Men Report More Opposite-Sex Sexual Partners Than Women? Analysis of the Gender Discrepancy in a British National Probability Survey. J. Sex Res. 56, 1-8. https://doi.org/10.1080/00224499.2018.1481193

Monsonego, J., Bohbot, J.M., Pollini, G., Krawec, C., Vincent, C., Merignargues, I., Haroun, F., Sednaoui, P., Monfort, L., Dachez, R., Syrjänen, K., 2005. Performance of the Roche AMPLICOR human papillomavirus (HPV) test in prediction of cervical intraepithelial neoplasia (CIN) in women with abnormal PAP smear. Gynecol. Oncol. 99, 160-168. https://doi.org/10.1016/j.ygyno.2005.05.030

Murall, C.L., McCann, K.S., Bauch, C.T., 2014. Revising ecological assumptions about Human papillomavirus interactions and type replacement. J. Theor. Biol. 350, 98-109. https://doi.org/10.1016/j.jtbi.2013.12.028 
medRxiv preprint doi: https://doi.org/10.1101/2021.02.23.21252238; this version posted February 24, 2021. The copyright holder for this preprint (which was not certified by peer review) is the author/funder, who has granted medRxiv a license to display the preprint in perpetuity.

It is made available under a CC-BY-ND 4.0 International license .

Olsen, J., Jepsen, M.R., 2010. Human papillomavirus transmission and cost-effectiveness of introducing quadrivalent HPV vaccination in Denmark. Int. J. Technol. Assess. Health Care 26, 183-191. https://doi.org/10.1017/S0266462310000085

Pinotti, F., Fleury, É., Guillemot, D., Böelle, P.-Y., Poletto, C., 2019. Host contact dynamics shapes richness and dominance of pathogen strains. PLoS Comput. Biol. 15, e1006530. https://doi.org/10.1371/journal.pcbi.1006530

Pons-Salort, M., Letort, V., Favre, M., Heard, I., Dervaux, B., Opatowski, L., Guillemot, D., 2013. Exploring individual HPV coinfections is essential to predict HPV-vaccination impact on genotype distribution: a model-based approach. Vaccine 31, 1238-1245. https://doi.org/10.1016/j.vaccine.2012.11.098

Poolman, E.M., Elbasha, E.H., Galvani, A.P., 2008. Vaccination and the evolutionary ecology of human papillomavirus. Vaccine 26 Suppl 3, C25-30. https://doi.org/10.1016/j.vaccine.2008.04.010

Qu, W., Jiang, G., Cruz, Y., Chang, C.J., Ho, G.Y., Klein, R.S., Burk, R.D., 1997. PCR detection of human papillomavirus: comparison between MY09/MY11 and GP5+/GP6+ primer systems. J. Clin. Microbiol. 35, 1304-1310.

Ramanakumar, A.V., Naud, P., Roteli-Martins, C.M., de Carvalho, N.S., de Borba, P.C., Teixeira, J.C., Blatter, M., Moscicki, A.-B., Harper, D.M., Romanowski, B., Tyring, S.K., Ramjattan, B., Schuind, A., Dubin, G., Franco, E.L., HPV-007 Study Group, 2016. Incidence and duration of type-specific human papillomavirus infection in high-risk HPV-naïve women: results from the control arm of a phase II HPV-16/18 vaccine trial. BMJ Open 6, e011371. https://doi.org/10.1136/bmjopen-2016-011371

Riethmuller, D., Gay, C., Bertrand, X., Bettinger, D., Schaal, J.P., Carbillet, J.P., Lassabe, C., Arveux, P., Seilles, E., Mougin, C., 1999. Genital human papillomavirus infection among women recruited for routine cervical cancer screening or for colposcopy determined by Hybrid Capture II and polymerase chain reaction. Diagn. Mol. Pathol. Am. J. Surg. Pathol. Part B 8, 157-164. https://doi.org/10.1097/00019606-199909000-00009

Safaeian, M., Porras, C., Schiffman, M., Rodriguez, A.C., Wacholder, S., Gonzalez, P., Quint, W., van Doorn, L.-J., Sherman, M.E., Xhenseval, V., Herrero, R., Hildesheim, A., Costa Rican Vaccine Trial Group, 2010. Epidemiological study of anti-HPV16/18 seropositivity and subsequent risk of HPV16 and -18 infections. J. Natl. Cancer Inst. 102, 1653-1662. https://doi.org/10.1093/jnci/djq384

Santé publique France, 2019. Cancer du col de l'utérus [WWW Document]. URL https://www.santepubliquefrance.fr/maladies-et-traumatismes/cancers/cancer-du-col-de-Iuterus/la-maladie/\#tabs (accessed 7.6.20).

Schneeberger, A., Mercer, C.H., Gregson, S.A.J., Ferguson, N.M., Nyamukapa, C.A., Anderson, R.M., Johnson, A.M., Garnett, G.P., 2004. Scale-free networks and sexually transmitted diseases: a description of observed patterns of sexual contacts in Britain and Zimbabwe. Sex. Transm. Dis. 31, 380-387. https://doi.org/10.1097/00007435-200406000-00012

Serrano, B., Alemany, L., Tous, S., Bruni, L., Clifford, G.M., Weiss, T., Bosch, F.X., de Sanjosé, S., 2012. Potential impact of a nine-valent vaccine in human papillomavirus related cervical disease. Infect. Agent. Cancer 7, 38. https://doi.org/10.1186/1750-9378-7-38

Shiboski, S., Padian, N.S., 1996. Population- And Individual-Based Approaches To The Design And Analysis Of Epidemiologic Studies Of Sexually Transmitted Disease Transmission. J. Infect. Dis. 174, S188-S200. https://doi.org/10.1093/infdis/174.Supplement_2.S188 
medRxiv preprint doi: https://doi.org/10.1101/2021.02.23.21252238; this version posted February 24, 2021. The copyright holder for this preprint (which was not certified by peer review) is the author/funder, who has granted medRxiv a license to display the preprint in It is made available under a CC-BY-ND 4.0 International license.

Spinillo, A., Dal Bello, B., Alberizzi, P., Cesari, S., Gardella, B., Roccio, M., Silini, E.M., 2009. Clustering patterns of human papillomavirus genotypes in multiple infections. Virus Res. 142, 154-159. https://doi.org/10.1016/j.virusres.2009.02.004

Tota, J.E., Ramanakumar, A.V., Jiang, M., Dillner, J., Walter, S.D., Kaufman, J.S., Coutlée, F., Villa, L.L., Franco, E.L., 2013. Epidemiologic approaches to evaluating the potential for human papillomavirus type replacement postvaccination. Am. J. Epidemiol. 178, 625-634. https://doi.org/10.1093/aje/kwt018

Tota, J.E., Struyf, F., Sampson, J.N., Gonzalez, P., Ryser, M., Herrero, R., Schussler, J., Karkada, N., Rodriguez, A.C., Folschweiller, N., Porras, C., Schiffman, M., Schiller, J.T., Quint, W., Kreimer, A.R., Wheeler, C.M., Hildesheim, A., 2020. Efficacy of the AS04-Adjuvanted HPV16/18 Vaccine: Pooled Analysis of the Costa Rica Vaccine and PATRICIA Randomized Controlled Trials. JNCl J. Natl. Cancer Inst. https://doi.org/10.1093/jnci/djz222

Trottier, H., Mahmud, S., Prado, J.C.M., Sobrinho, J.S., Costa, M.C., Rohan, T.E., Villa, L.L., Franco, E.L., 2008. Type-specific duration of human papillomavirus infection: implications for human papillomavirus screening and vaccination. J. Infect. Dis. 197, 1436-1447. https://doi.org/10.1086/587698

Vaccarella, S., Söderlund-Strand, A., Franceschi, S., Plummer, M., Dillner, J., 2013. Patterns of human papillomavirus types in multiple infections: an analysis in women and men of the high throughput human papillomavirus monitoring study. PloS One 8, e71617. https://doi.org/10.1371/journal.pone.0071617

Van de Velde, N., Boily, M.-C., Drolet, M., Franco, E.L., Mayrand, M.-H., Kliewer, E.V., Coutlée, F., Laprise, J.-F., Malagón, T., Brisson, M., 2012. Population-level impact of the bivalent, quadrivalent, and nonavalent human papillomavirus vaccines: a model-based analysis. J. Natl. Cancer Inst. 104, 1712-1723. https://doi.org/10.1093/jnci/djs395

Van de Velde, N., Brisson, M., Boily, M.-C., 2010. Understanding differences in predictions of HPV vaccine effectiveness: A comparative model-based analysis. Vaccine $28,5473-5484$. https://doi.org/10.1016/j.vaccine.2010.05.056

Walboomers, J.M., Jacobs, M.V., Manos, M.M., Bosch, F.X., Kummer, J.A., Shah, K.V., Snijders, P.J., Peto, J., Meijer, C.J., Muñoz, N., 1999. Human papillomavirus is a necessary cause of invasive cervical cancer worldwide. J. Pathol. 189, 12-19. https://doi.org/10.1002/(SICI)10969896(199909)189:1<12::AID-PATH431>3.0.CO;2-F

Xi, L.F., Edelstein, Z.R., Meyers, C., Ho, J., Cherne, S.L., Schiffman, M., 2009. Human papillomavirus types 16 and 18 DNA load in relation to coexistence of other types, particularly those in the same species. Cancer Epidemiol. Biomark. Prev. Publ. Am. Assoc. Cancer Res. Cosponsored Am. Soc. Prev. Oncol. 18, 2507-2512. https://doi.org/10.1158/1055-9965.EPI-09-0482 